\title{
Genetic variability of Herpailurus yagouaroundi, Puma concolor and Panthera onca (Mammalia, Felidae) studied using Felis catus microsatellites
}

\author{
Vanessa Roma Moreno ${ }^{1}$, Alexéia Barufatti Grisolia ${ }^{1}$, Francine Campagnari ${ }^{1}$, Marcela Milazzotto ${ }^{1}$, \\ Cristina Harumi Adania ${ }^{2}$, José Fernando Garcia ${ }^{3}$ and Edislane Barreiros de Souza ${ }^{4}$ \\ ${ }^{1}$ UNESP, Universidade Estadual Paulista, Instituto de Biociências, Departamento de Genética, Botucatu, \\ SP, Brazil. \\ ${ }^{2}$ Associação Mata Ciliar, Jundiaí, São Paulo, Brazil. \\ ${ }^{3}$ UNESP, Universidade Estadual Paulista, Faculdade de Medicina Veterinária, Departamento de Apoio, \\ Produção e Saúde Animal, Araçatuba, SP, Brazil. \\ ${ }^{4}$ UNESP, Universidade Estadual Paulista, Faculdade de Ciências e Letras, Departamento de Ciências \\ Biológicas, Assis, SP, Brazil.
}

\begin{abstract}
We used four microsatellite loci (Fca08, Fca45, Fca77 and Fca96) from the domestic cat, Felis catus, to investigate genetic variability in specimens of Herpailurus yagouaroundi (jaguarundi, otter cat, eyra), Puma concolor (cougar, mountain lion, puma) and Panthera onca (jaguar) held in various Brazilian zoos. Samples of DNA from the cats were PCR amplified and then sequenced before being analyzed using the CERVUS program. Our results show a mean polymorphic information content (PIC) of 0.83 for $H$. yagouaroundi, 0.66 for $P$. concolor and 0.69 for $P$. onca and a mean of 10.3 alleles for the Fca08 locus, 5.3 for Fca 45, 9 for $F c a 77$ and 14 for $F c a 96$. These results indicate a relatively high level of genetic diversity for the specimens studied.
\end{abstract}

Key words: genetic variability, mammals, felines, microsatellites.

Received: October 19, 2004; Accepted: September 21, 2005.

Brazil has the highest number of aquatic and terrestrial species and is the leading country in respect to biological diversity. Brazil, Indonesia and Mexico are the three countries with the richest mammalian fauna, Brazil currently having 460 species of mammals and this number is expected to increase as new species are described (Mittermeier, 1994).

Felines are an important component of the worldwide fauna, the family Felidae (Mammalia, Carnivora) comprising 37 species which occur naturally in almost every area of the world except for some insular regions such as Australia, New Guinea and New Zealand, Japan, Madagascar, Oceania, the poles and some Caribbean islands such as the West Indies (Nowak, 1991).

The Neotropics are home to ten feline species (Herpailurus yagouaroundi (jaguarundi, otter cat, eyra), Leopardus pardalis (the leopard cat), Leopardus wiedii (the margay), Leopardus tigrinus (the oncilla), Oncifelis geoffroi (Geoffroy's Cat), Oncifelis colocolo (the pampas

Send corrrespondence to Vanessa Roma Moreno. Rua General Carneiro, n. 328, Vila Boa Vista, 19806-100 Assis, SP, Brazil. E-mail: bio_vanessa@hotmail.com. cat), Oncifelis guign (the kodkod), Oreailurus jacobita (the Andes cat), Puma concolor (cougar, mountain lion, puma) and Panthera onca (jaguar)), of which only the Andes cat and the kodkod do not occur naturally in Brazil (Oliveira, 1994). All of the Neotropical Felidae are to some extent threatened with extinction, mainly due to indiscriminate hunting and large scale modification of their habitat (Crawshaw Jr., 1997).

Microsatellites consist of small DNA fragments of about 10-100 base pairs (bp) that contain repetitive elements displaying tandem repeats of $1-6 \mathrm{bp}$, variation in the number of repeats resulting in these loci having a high polymorphism information (PIC). The heterozygosity of microsatellite loci was first described in humans, but microsatellites have been found to be abundant, randomly distributed and highly polymorphic in all eukaryotic organisms so far investigated (Weber and May, 1989). Microsatellites are co-dominant markers (i.e. heterozygotes can be distinguished from the homozygotes) which can be amplified by the polymerase chain reaction (PCR) and generally show a level of heterozygosity in excess of 0.7 (Ferreira and Grattapaglia, 1998). One of the advantages of 
using microsatellite loci is that primers for these loci can be used in species other than that for which they were originally designed. For example Moore et al. (1991) tested 48 ovine primers and found that 27 (42\% of which presented polymorphism) successfully amplified the same markers in bovine DNA, while Bowcock et al. (1994) found that human primer pairs successfully their corresponding microsatellites in chimpanzee, gorilla and orangutan.

Our study was designed to use Felis catus microsatellite markers (Menotti-Raymond and O'Brien, 1995) in a genetic variability study of three neotropical Brazilian feline species $H$. yagouaroundi, $P$. concolor and $P$. onca.

Blood samples were collected from specimens of $H$. yagouaroundi $(\mathrm{n}=36), P$. concolor $(\mathrm{n}=18)$ and $P$. onca $(\mathrm{n}=39) \mathrm{kept}$ at a wide variety of Brazilian zoos (Table 1). The samples were humanly collected without suffering to the animal by the workers from the Riverine Forest Association (Associação Mata Ciliar, Jundiaí-SP, Brazil) and analyzed at the Genetics Laboratory at the Assis campus of São Paulo State University (Laboratório de Genética, FCL, UNESP, Assis, SP). Our methodology was standardized using a blood sample from the domestic cat (Felis catus) supplied by the Marylin Menotti-Raymond from the Laboratory of Genomic Diversity, Frederick, Maryland, USA.

Total DNA was isolated from white blood cells using proteinase $\mathrm{K}$ digestion and treatment with phenol/chloroform (Sambrook et al., 1989). The primers used (Table 2 ) were the four $F$. catus dinucleotide primers developed by Menotti-Raymond and O'Brien (1995) who had tested them in four feline species. The microsatellite loci were PCR amplified in a final volume of $10 \mu \mathrm{L}$ containing $10 \mathrm{ng}$ of feline genomic DNA, 1.5 $\mu \mathrm{L}$ of PCR buffer (containing $200 \mathrm{mM}$ Tris- $\mathrm{HCl}$ and $500 \mathrm{mM} \mathrm{KCl}), 25 \mathrm{mM} \mathrm{MgCl}_{2}$, $250 \mu \mathrm{M}$ of each dNTP, 2 units of AmpliTaq Gold ( $\left.5 \mathrm{U}_{\mu} \mathrm{L}^{-1}\right)$, 2.5 pmol of each forward and reverse oligonucleotide primer $\left(10\right.$ pmol $\left.\mu \mathrm{L}^{-1}\right)$ and ultra-pure water. The forward sequences were fluorescently labeled using tetramethylrhodamine (TAMRA) for Fca08, hexachloro-6-carboxyfluorescine (HEX) for $F c a 45$ and 6-carboxyfluorescine (FAM) for $F c a 77$ and $F c a$ 96. Amplification was performed using a PTC-100 thermocycler (MJ-Research) in accordance with the conditions described by MenottiRaymond et al. (1999), i.e. 1 cycle of $94{ }^{\circ} \mathrm{C}$ for $10 \mathrm{~min}$; 10 cycles of $94^{\circ} \mathrm{C}$ for $15 \mathrm{~s}, 55^{\circ} \mathrm{C}$ for $15 \mathrm{~s}, 72^{\circ} \mathrm{C}$ for $30 \mathrm{~s}$; 20 cycles of $89^{\circ} \mathrm{C}$ for $15 \mathrm{~s}, 55^{\circ} \mathrm{C}$ for $15 \mathrm{~s}, 72^{\circ} \mathrm{C}$ for $30 \mathrm{~s}$; and 1 cycle of $72{ }^{\circ} \mathrm{C}$ for $30 \mathrm{~min}$. At the end of the reaction the samples were cooled to $4{ }^{\circ} \mathrm{C}$.

The amplified microsatellite loci were separated using capillary electrophoresis in an automatic genetic analyzer (ABI PRISM ${ }^{\circledR} 310$ Analyzer, Applied Biosystems). For each electrophoretic run $12 \mu \mathrm{L}$ of amplified sample containing the PCR products was mixed with $12 \mu \mathrm{L}$ of deionized formamide and $0.5 \mu \mathrm{L}$ of ROX 500 molecular weight marker (Applied Biosystems), a control consisting of unamplified sample also being run. Before sequencing the samples were denatured in the thermocycler at $95^{\circ} \mathrm{C}$ for 5 min and rapidly cooled in ice. The electrophoresis products were developed using Gel POP $4^{\mathrm{TM}}$ (Performance Optimized Polymer 4, Applied Biosyestems) and each sample was run for approximately $25 \mathrm{~min}$. The electrophoresis data were stored on the ABI 310 system using the ABI Collec-

Table 1 - Zoo location (all in Brazil) and specimen registration number of the felines investigated in the current work.

\begin{tabular}{lll}
\hline \multicolumn{1}{c}{ Herpailurus yagouaroundi } & \multicolumn{1}{c}{ Puma concolor } \\
\hline Ilha Solteira-SP; 003 & Varginha-MG; 013, 014 & \multicolumn{1}{c}{ Panthera onca } \\
São Paulo-SP; 141, 142 & Goiânia-Go; O15 & Campinas-SP; 001, 004, 002, Pintada 1 (no number) \\
Pedreira-SP; 022, 021 & Ubá-MG; 022 & Pedreira-SP; Black (no number) \\
Campinas-SP; 010 & Pomerode-SC; 61 & Uberlândia-MG; 032 \\
Garça-SP; 20 & Uberaba-MG; 040 & Ipatinga-MG; 016 \\
São José do Rio Preto-SP; 17 & Campinas-SP; 01, 002 & Alfenas-MG; 05, 025 \\
Sorocaba-SP; 12, 014, 11, 15, 13, 18 & Cascavel-PR; 062, 064, 063 & Muriaé-MG; 18, 17 \\
Catanduva-SP; 016 & Curitiba-PR; 087, 086, 085, 088, 089, 090 & Pouso Alegre-MG; 026 \\
Bauru-SP; 19 & Ipatinga-MG; 011 & Pomerode-SC; 059, 061, 60 \\
Jundiaí-SP; 027, 028, 051, 50, 029 & & Varginha-MG; 022 \\
Uberlândia-MG; 048 & & Camboriú-SC; 67, 64, 68, 66, 65, 63, 69 \\
Varginha-MG; 035, 036 & & Goiânia-GO; 072, 037, 071, 007, 009 \\
Mogi Mirim-SP; 006 & & Cascavel-PR; 078, 073, 079, 080, 075, 076, 077, 074 \\
Goiânia-GO; 042, 043, 044 & & Curitiba-PR; 107, 106, 109 \\
Ipatinga-MG; 034, 033 & & \\
Brasília-DF; 041, 040, 039, 038 & & \\
Maringá-PR; 061 & & \\
Uberaba-MG; 047 & & \\
\hline
\end{tabular}

Key to Brazilian states: $\mathrm{DF}=$ Distrito Federal; $\mathrm{GO}=$ Goiás; $\mathrm{MG}=$ Minas Gerais; $\mathrm{PR}=$ Paraná; $\mathrm{SC}=$ Santa Catarina; $\mathrm{SP}=$ São Paulo. 
Table 2 - Domestic cat (Felis catus) microsatellite loci used in amplifying the feline samples. Data from Menotti-Raymond and O'Brien (1995) and Menotti-Raymond et al. (1999).

\begin{tabular}{|c|c|c|c|c|}
\hline Microsatellite loci & GenBank & Chromosome location & Number of repetitions & Primer sequence \\
\hline Fca 08 & AF130476 & A1 & $(\mathrm{CA})_{24}$ & $\begin{array}{l}\text { 5'ACTGTAAATTTCTGAGCTGGCC3', } \\
\text { 3'TGACAGACTGTTCTGGGTATGG5' }\end{array}$ \\
\hline Fca 45 & AF130489 & A1 & $(\mathrm{CA})_{15}$ & $\begin{array}{l}\text { 5'TGAAGAAAAGAATCAGGCTGTG3' } \\
\text { 3'GTATGAGCATCTCTGTGTTCGTG5' }\end{array}$ \\
\hline Fca 77 & AF130506 & $\mathrm{C} 2$ & $(\mathrm{CA})_{20}$ & $\begin{array}{l}\text { 5'GGCACCTATAACTACCAGTGTGA3', } \\
\text { 3'ATCTCTGGGGAAATAAATTTTGG5' }\end{array}$ \\
\hline Fca 96 & AF130519 & A2 & $(\mathrm{CA})_{17}$ & $\begin{array}{l}\text { 5'CACGCCAAACTCTATGCTGA3', } \\
\text { 3'CAATGTGCCGTCCAAGAAAC5' }\end{array}$ \\
\hline
\end{tabular}

tion software licensed by Applied Biosystems and allele sizes were determined using version 2 of the ABI GENESCAN $^{\circledR} 500$ and GENOTYPER ${ }^{\circledR}$ programs. The results were analyzed using the CERVUS program model 2.0 (Marshall et al., 1998). For each microsatellite locus and species genetic diversity was measured based on the number of alleles and the polymorphism information content (PIC) (Botstein et al., 1980) and the efficiency of each primer was calculated from the relationship between the number of samples analyzed and the number of positive amplifications of each loci for each species.

The success of inter-species microsatellite amplification depends on conservation of the primer sequence between species (Menotti-Raymond and O'Brien, 1995). Studies of $F$. catus microsatellite primers have shown that they produce amplification products of similar sizes in other feline species, loci containing the dinucleotide repetitions $(\mathrm{dC} \cdot \mathrm{dA})_{\mathrm{n}}(\mathrm{dG} \cdot \mathrm{dT})_{\mathrm{n}}$ being highly polymorphic in domestic cats, lions, cheetahs, leopards and Geoffroy's cats (Menotti-Raymond and O'Brien, 1995; Shankaranarayanan et al., 1997). The use of $F$. catus microsatellite primers in related felines has also been described by Eizirik et al. (2001) who used 29 F. catus microsatellite markers to investigate genetic diversity in $42 P$. onca specimens.

Our results show that the F. catus Fca 08, Fca 45, Fca 77 and $F$ ca 96 primers efficiently amplified the corresponding markers in $H$. yagouaroundi, $P$. concolor and $P$. onca at an efficiency of between 61 and 100\%. This indicates that even though there was genetic diversity in the specimens conservation of primer sequences was significant in these species.

Microsatellite markers are known to generates a large number of alleles (multiallelism). Table 3 showing the number of $H$. yagouaroundi, $P$. concolor and $P$. onca alleles and the PIC for each of the microsatellite loci studied. Our results show that the number of alleles found for each of the loci in the three species studied was equal to or greater than that seen in F. catus and other representative felines (MenottiRaymond and O'Brien, 1995), suggesting the presence of new and exclusive alleles the $H$. yagouaroundi, $P$. concolor and $P$. onca specimens studied by us and that many differently-sized alleles (in base-pairs) are shared and conserved among $H$. yagouaroundi, $P$. concolor and $P$. onca.

Table 3 shows that the Fca 96 locus exhibited the largest number of alleles (17 in $H$. yagouaroundi and 13 in $P$. concolor) and was therefore the most polymorphic loci, although in F. catus this locus has been reported to be less polymorphic (Menotti-Raymond and O'Brien, 1995). The $F$ ca 96 locus showed 12 alleles in $P$. onca, the same number as the Fca 08 locus. Since genetic variance within a population is described by the number and frequency of alleles in each locus (Futuyma, 1986) our microsatellite marker results indicate that despite $H$. yagouaroundi, $P$. concolor and $P$. onca being threatened species they still presents a reasonable level of genetic diversity. In spite of the fact that there were differences in terms of the quantity of alleles per loci and the felines studied between our work and that of other published researchers, our results are equal or, very often, superior to those previously reported for the same oligonucleotides in other felines.

The polymorphism frequency of a microsatellite sequence is frequently related to the number of repeats and microsatellites consisting of over 10 repeats are considered to be highly informative, polymorphism information content (PIC) values being used to determine the potential usefulness of markers for each locus (DeWoody et al., 1995). Because of their co-dominant expression and multiallelism microsatellite markers exhibit the highest PIC values of all mark-

Table 3 - Allele and polymorphic information content (PIC) data for the four microsatellite loci in the three feline species investigated.

\begin{tabular}{|c|c|c|c|c|c|c|}
\hline \multirow[b]{3}{*}{ Microsatellite loci } & \multicolumn{6}{|c|}{ Feline species } \\
\hline & \multicolumn{2}{|c|}{ Herpailurus yagouaroundi } & \multicolumn{2}{|c|}{ Puma concolor } & \multicolumn{2}{|c|}{ Panthera onca } \\
\hline & Number of alleles & PIC & Number of alleles & PIC & Number of alleles & PIC \\
\hline Fca 08 & 9 & 0.73 & 10 & 0.75 & 12 & 0.72 \\
\hline Fca 45 & 8 & 0.82 & 5 & 0.41 & 3 & 0.48 \\
\hline Fca 77 & 9 & 0.83 & 9 & 0.63 & 9 & 0.71 \\
\hline Fca 96 & 17 & 0.92 & 13 & 0.86 & 12 & 0.45 \\
\hline
\end{tabular}


ers (Ferreira and Grattapaglia, 1998), and it has also been pointed out that PIC values higher than 0.5 indicate high polymorphism and that markers with this, or higher, level of polymorphism are highly informative for genetic studies and extremely useful in distinguishing the polymorphism rate of a marker at a specific locus (DeWoody et al., 1995).

We found that for H. yagouaroundi the highest PIC value was 0.92 for the $F c a 96$ locus and that the lowest PIC value for this species was 0.73 for the $F c a 08$ locus (Table 3 ) and that in this species the overall PIC for the four microsatellite loci was quite high, indicating that the all the microsatellites studied are good and representative markers able to genetically differentiate or characterize individuals of a $H$. yagouaroundi population. In $P$. concolor the Fca 96 locus showed the highest polymorphism rate with a PIC value of 0.86 while the $F c a 08$ locus had a PIC value of 0.75 (Table 3), both these loci being efficient and informative in this species. The $P$. concolor Fca 45 locus had the lowest PIC value (0.41) of all the loci studied in the three species (Table 3). For $P$. onca the highest PIC values were 0.72 for the Fca 08 locus and 0.71 for the Fca 77 locus, while the PIC values of 0.48 for the $F c a 45$ locus and 0.45 for the $F c a$ 96 locus indicated a low level of polymorphism for these loci (Table 3). Thus Fca 08 and Fca 77 could be used successfully in $P$. onca genetic diversity assessment studies.

Table 3 shows that the $F c a 08$ microsatellite locus gave the most consistent PIC values in all three species studied and was in all cases equal to or higher than 0.72 . For H. yagouaroundi the highest PIC values were those for the Fca $45, F c a 77$ and $F c a 96$ loci, ranging from 0.82 to 0.92 . However, for $P$. concolor and $P$. onca the $F c a 45$ locus gave PIC values of less than 0.5 and the same was true for the $P$. onca Fca 96 locus, these three loci being considered as having an average level of polymorphism in these species (Table 3).

In their study on deer, DeWoody et al. (1995) found PIC values between 0.63 and 0.86 for five out of seven microsatellites and regarded these as indicating a high level of polymorphism and the markers as being highly informative for genetic studies. Our results indicate that in the three feline species studied by us the microsatellite loci used presented a medium to high level of polymorphism and appear to be suited for genetic diversity studies in these species.

\section{Acknowledgements}

We would like to show our appreciation to UNESP, Botucatu-SP, Araçatuba-SP and Assis-SP and the Brazilian agency CAPES for financial support and to Ana Paula Martins Machado Villar.

\section{References}

Botstein D, White RL, Skolnick M and Davis RW (1980) Construction of a genetic linkage map in man using restriction fragment length polymorphisms. American Journal of $\mathrm{Hu}-$ man Genetics 32:314-331.

Bowcock AM, Ruiz-Linares A, Tomfohrde J, Minch E, Kidd JR and Cavalle-Sforza LL (1994) High resolution of human evolutionary trees with polymorphic microsatellites. Nature 368:455.

Crawshaw Jr PG (1997) Recomendações para um modelo de pesquisa sobre felídeos neotropicais. In: Valladares-Padua $\mathrm{C}$ and Bodmer RE (orgs) Manejo e Conservação da Vida Silvestre no Brasil. Sociedade Civil Mamirauá, Belém, pp 70-94.

DeWoody JA, Honeycutt RL and Skow LC (1995) Microsatellite markers in white-tailed deer. The Journal of Heredity 86:317-319.

Eizirik E, Kim J, Menotty-Raymond M, Crawshaw Jr PG, O'Brien SJ and Johnson WE (2001) Conservation genetics of Jaguars: Phylogeography, population history and conservation genetics of jaguars (Panthera onca, Mammalia, Felidae). Mol Ecol 10:65-79.

Ferreira ME and Grattapaglia D (1998) Introdução ao Uso de Marcadores Moleculares em Análise Genética. 3. ed. Embrapa, Brasília, 220 pp.

Futuyma DJ (1986) Evolutionary Biology. 2nd edition. Sinauer Associates, Inc., Sunderland, 600 pp.

Marshal TC, Slate J, Kruuk L and Pemberton JM (1998) Statistical confidence for likelihood-based paternity inference in natural populations. Mol Ecol 7:639-655.

Menotti-Raymond M and O'Brien SJ (1995) Evolutionary conservation of ten microsatellite loci in four species of Felidae. The Journal of Heredity 86:319-322.

Menotti-Raymond M, David VA, Lyons LA, Schäffer AA, Tomlin JF, Hutton MK and O'Brien SJ (1999) A genetic linkage map of microsatellites in the domestic cat (Felis catus). Genomics 57:9-23.

Mittermeier RA (1994) Prefácio. In: Fonseca GAB, Rylands AB, Costa CMR, Machado RB and Leite LR (eds), Livro Vermelho dos Mamíferos Brasileiros Ameaçados de Extinção. Fundação Biodiversitas, Belo Horizonte, pp xi-xiii.

Moore SS, Sargent LL, King TJ, Mattick JS and Hetzel DJS (1991) The conservation of dinucleotide microsatellites among mammalian genomes allows the use of heterologous PCR primer pairs in closely related species. Genomics 10:654-660.

Nowak RM (1991) Walker's Mammals of the World. 5th edition, v. II. The Johns Hopkins University Presser, Baltimore and London, $1630 \mathrm{pp}$.

Oliveira TG (1994) Neotropical cats: Ecology and conservation. EDUFMA, São Luís, 244 pp.

Sambrook J, Fristsch EF and Maniatis T (1989) A Molecular Cloning: A Laboratory Manual. 2nd edition. Cold Spring Harbor Laboratory Press, New York.

Shankaranarayanan P, Banerjee M, Kacker RK, Aggarwal RK and Singh L (1997) Genetic variation in asiatic lions and indian tigers. Electrophoresis 18:1693-1700.

Weber JL and May PE (1989) Abundant class of human DNA polymorphisms which can be typed using the polymerase chain reaction. Am J Hum Genet 44:388-396.

Associate Editor: Sérgio Furtado dos Reis 